\title{
IAMJ
}

INTERNATIONAL

AYURVEDIC

MEDICAL JOURNAL

\section{PHYSIOLOGICAL ASPECTS OF ASTHIDHATU}

\author{
Neetu Soni ${ }^{1}$, Rashmi Pradhan ${ }^{2}$, Bhupendra Kumar Mishra ${ }^{3}$ \\ ${ }^{1}$ PG Scholar, ${ }^{2}$ Head of Department, ${ }^{3}$ Reader, Department of Sharir Kriya \\ Govt. (Auto.) Ayurved College, Gwalior, Madhya Pradesh, India
}

Corresponding Author: sonineetu907@gmail.com

\section{https://doi.org/10.46607/iamj3209102021}

(Published Online: October 2021)

Open Access

(C) International Ayurvedic Medical Journal, India 2021

Article Received: 27/09//2021 - Peer Reviewed: 07/10/2021 - Accepted for Publication: 08/10/2021

\section{Check for updates}

\begin{abstract}
Ayurveda is an ancient medical science which is related to health. Ayurveda described three basic physiological constitution of the body they are: Dosha, Dhatu and mala. Dhatu are structural unit of the body. Asthi is fifth dhatu among saptadhatu. In modern science asthidhatu relate with bones and cartilage. Bones store minerals such as calcium. Metabolic bone diseases are caused by minerals and vitamins deficiency. Asthidhatu is resultant of action of medoagni on medodhatu and is responsible for nourishing majjadhatu. It supports the basic structures, protect vital organs, nourishing the nervous tissue. Health refers to the moderate quantity of asthidhatu while disorders may develop when any vitiation occur. Just as asthi dhatu (Bones) contribute to health, diseases related to bones can disrupt the body. This paper attempts to understand concepts of Asthidhatu for maintain health and prevention from diseases related to the bone.
\end{abstract}

Keywords: Health, Asthidhatu ksaya-Vruddhi, functions

\section{INTRODUCTION}

Asthidhatu is an important dhatu among many other dhatus of the body. Keekas and kulya are synonyms of asthi-Amarkosh. Just as tree stand with the help of inner hard core of sara, in the same way human also stands with the help of the inner hard core called $a s t h i^{l}$. It mainly involved in providing the shape of 
body and protecting vital organs from external shock. Sharir dharan is main function of asthidhatu ${ }^{2}$. The balance of asthidhatu helps in maintains the health in individual whereas any disturb in the function of $a s$ thidhatu leads to disease. Consumption of various nidaan can lead to disturbance in asthidhatu in the form of vruddhi and ksaya, which further gives rise to many other bone diseases.

\section{Origin of Asthidhatu}

Asthidhatu originated in intra- uterine life further like other dhatu it gets nourishment and growth by Aahar rasa. Part of medodhatu reaches next strotas which is asthivaha strotas; it participates in the production of asthidhatu. Asthidhatvagni acts on the nutrients coming from aahar rasa and medovaha strotas and give rise to Asthidhatu proper. By the action of ushma present in meda itself and mahabhoot (Prithivi, Vayu and Agni) this bringing hardness to it and produce asthidhatu. To produce hard bone from fluidly and unctuous quality of medodhatu, Vayu is needed to dry fluid, Prithivi is needed for solidity and Agni is needed for bring down Khara property. ${ }^{3}$

\section{Panchbhautik Constitution of Asthidhatu}

Although every substance is made up of pachmahabhoot these are Aakash, Vayu, Agni, Jal and prithvi. In Asthidhatu, there are prithivi, vayu and Agni mahabhoot are dominant. Because of this asthidhatu have qualities of these mahabhoot. Due to prithivi mahabhoot asthi is heavy. Dryness in asthi is caused by vayu and the roughness is found in asthi due to agni mahabhoot. ${ }^{4}$ Thus, these mahabhoot gives roughness, toughness, dryness and hardness to the asthi.

\section{Location of Asthidhatu, Asthivaha srotas}

Since it is one of the seven dhatuvah, it must be present throughout the body. It may be present in large quantities in some places and may act exclusively in the context of certain organs. Such places are the places of the dhatus. Location of asthidhatu is in its srotas that is called asthivaha srotas. Acharya charak has discussed about asthivaha srotas, whereas sushruta has not described it. According to charak, mulasthana of asthivaha srotas are principal organs they are meda and jaghana. ${ }^{5}$ Chakrapani said that srotas mula is origin place so that origin of asthi has been considered from meda and jaghana. Excessive exercise, excessive stretching, trauma or excessive intake of Vata prakopaka Aahar and Vihar can lead to Asthivaha Srotas Dusti. ${ }^{6}$

Total number of Asthi

Carak samhita ${ }^{7}-360$

Sushruta samhita ${ }^{8}-300$

Astanga hridaya ${ }^{9}-360$

Modern science - 206

\section{Types of Asthidhatu ${ }^{10}$}

1. Kapala - These are flat bone, present in janu, Nitamba, Amsa, Ganda, Talu, Shankha, Sira.

2. Ruchaka - Teeth are considered as ruchakasthi and are utilized to chew food.

3. Taruna - These are soft bone and not fully ossified. They present in Ghrana, Karna, Greeva, Akshikuta.

4. Valaya - They are round. Asthi of Uru, Parshva, Prustha are valayasthi.

5. Nalaka - All bones present in human body are nalakasthi except above mentioned

\section{Poshan of Asthidhatu}

When the action of asthiagni take place on the part of meda which form asthi in asthivaha srotas. Then asthi is produced in the Prasad bhaga. Bone building constituents present in aahar rasa. On the adoption of selective discrimination, quality like bone can absorb so that asthidhatu continues to be nourished.

\section{Time taken in formation of Asthidhatu}

According to Sushruta Asthi gets nourishment on the $20^{\text {th }}$ day because Aahar rasa in every dhatu lasts for 3015 kala $^{11}$. Parashara said that on $6^{\text {th }}$ day asthi gets nourishment. Acharya charak mentioned that process of nutrition of all dhatu take place in continuous manner so that the fixed time of nutrition for each dhatu cannot be estimated. ${ }^{12}$

\section{Asthidharakala ${ }^{13}$}

Purishadhara Kala is the membrane that holds asthiagni and it is 5th Kala which exits in large intestine (pakwashaya). Pakwashaya (Large intestine) and asthi are home site of vata dosha. When any deformity like gas, constipation occurs in large intestine this deformity transferred to the bones that are more po- 
rous and filled with air. It can be related with case of osteoporosis. This relation suggests bone susceptibility to vata disorders. So that condition of Vriddhi and kshaya of Vata and Purisha affects all sites of Vata, especially Asthi Dhatu. Hence Purishadhara Kala is also known as Asthidhara Kala.

\section{Physical and chemical property of Asthidhatu} (Guna)

Main quality of asthidhatu is roughness. It is hard, tough, porous and powerful dhatu which gives support to entire body. ${ }^{14}$ Bones give Strength, resistance to compression, protect internal organs and motion due to muscles contraction, self-repair, site of hematopoiesis. $60 \%$ inorganic material formed by carbonate whereas $25 \%$ organic part mainly composed of type 1 collagen and other growth factors. $15 \%$ water present in bones. ${ }^{15}$

\section{Functions of Asthidhatu}

- Asthidhatu is responsible for proper posture of the body, and it also nourishes majja dhatu. ${ }^{16}$

- Function of asthidhatu is dharana to the living body. $^{17}$

- Bones are the basic structure of the human body and provide strength to the body.

- Just as the inner part of tree called sara holds the tree to upright so that human stay upright due to asthidhatu.

- Bones do not get destroyed even after the skin and soft tissue since they are sara. Muscles, sira, snayu and other structures are remaining in the body only with the help of bones because asthi get tightly bound by these structures and they keep body upright without deteriorating or falling off. $^{18}$

\section{Upadhatu of Asthidhatu}

According to Sarandhar samhita teeth are updhatu of asthidhatu. ${ }^{19}$

\section{Mala of Asthidhatu}

According to charak samhita and sushrut samhita, nails and loma (body hair) are mala of asthidhatu. ${ }^{20}$

\section{Characteristic of Asthisara individual}

$>$ Physical features- Asthisara purush has large and stout Parsni (Heel), Gulf (ankle), janu (knee), Artni (forearm), scapula, chin, head, joints of finger, bone, nails and teeth. ${ }^{21}$ Huge head, shoulder, tooth, chin, nails and bones are characteristic of asthisara individual. ${ }^{22}$ Here huge means measure of these organs more than anguli praman.

$>$ Mental traits- Asthisara purush are very enthusiastic, active, bear strain, have excellent and durable bodies and live for long.

\section{Features of Asthivruddhi}

Due to increase in asthidhatu causes overgrowth of bones and extra teeth. ${ }^{23}$ Dalhan adds increase hair on the head, body hairs, and nails also.

\section{Feature of Asthiksaya}

Due to diminution of asthidhatu; hair, nails, hair of beard including mustaches and teeth fall off. There is tiredness in the body and looseness of joints occurs. ${ }^{24}$ The reason behind it bone become thinner due to asthiksaya so that the joints do not fit completely and joint become loose. There is pain in the bone, breaking of teeth and nails, dryness in body. ${ }^{25}$ According to Dalhan teeth and nails also decay and along with its dryness entire body becomes dry. This shows relation between asthi and vayu.

Asthi Pradoshaja Vikara (diseases caused by vitiated bone tissue)

Adhyasthi (hypertrophy of the bones) Adhi danta (excess teeth) Dantabheda (cracking sensation in the teeth) Asthibheda, Shoola crackling sensation and pain in bone. Vivarnata, Kesa, Loma, Nakha, Smashru dosha, Kunakha, Asthi toda. There is a condition known as Osteoporosis which means porous bones or brittleness of the bones due to loss of bone tissue leading to increased risk of fractures. Abnormal growths of bone this condition can be related with Hyperostosis, Osteopetrosis, Calcaneal spur, Diaphyseal aclasis.

\section{Relation between Vata dosha and Asthidhatu}

All Acharya described bone as the place of vata that is why vata diseases often occur in the bones. When there is an increase or decrease of Pitta or Kapha there is also an increase or decrease of tissues and waste products associated with them. For example, if Pitta increases or decrease then sweat and blood also increase or decrease respectively except Vata Dosa 
and Asthidhatu. This relationship helps to find both the cause and treatment of disease. ${ }^{26}$

\section{CONCLUSION}

Health is defined by comparison of physiological parameters. The balance of dhatu which is called dhatusamya is one of the important parameters of a healthy person. From birth to death structure of asthi remains unchanged because of its dominance in prithivi mahabhoot. Asthi protect vital organs like heart by thoracic bone, brain by skull etc. Major role of bone is movement of body and give strength with the help of muscles. Excessive exercise, running, late night sleeping, carrying heavy loads, taking food with pungent and bitter, light, ruksha aahar are the reason of vitiation of vata and cause of bone disease. Disease and cause related to bone can be determined by Asraya and Asrayi relationship and that will also help in treatment.

\section{REFERENCES}

1. Susruta Samhita, Ayurved-Tattva-Sandipika Hindi Commentary by Ambikadutta Shastri Part 1 Chaukhambha Sanskrit Sansthan, Varanasi, Edition: Reprint,2016 Su.sha. 5/23 p:60

2. Susruta Samhita, Ayurved-Tattva-Sandipika Hindi Commentary by Ambikadutta Shastri Part 1 Chaukhambha Sanskrit Sansthan, Varanasi, Edition: Reprint,2016 Su.su. 15/7 p:75

3. Agnivesha; Charak Samhita, English commentary by R.K. Sharma, Bhagwan DashVol.4 Choukhamba Sanskrit Series Office, Varanasi, Edition2010, Ch.Chi.15/30p:19

4. Agnivesha; charak samhita, Vidyotini hindi Commentary by Sri Satya Narayan Sastri Vol.2 Chaukhmbha Bharti Academy, Varanasi, Reprint:2012, Cha.Chi. 15/30: p453.

5. Agnivesha; Charak Samhita, English Commentary by R. K. Sharma, Bhagwan DashVol.2 Choukhamba Sanskrit Series Office, Varanasi, Edition2010, Ch.vi.5/7-8: p174.

6. Agnivesha; Charak Samhita, English Commentary by R. K. Sharma, Bhagwan DashVol.2 Choukhamba Sanskrit Series Office, Varanasi, Edition2010, Ch.vi.5/17: p178.
7. 7Charaka Samhita with Vidyotini Hindi commentary by Pt. Kashinath Shastri \& Dr. Gorakhanatha Chaturvedi, Part-1, Published by Chaukhambha Bharti Academy Varanasi, 22nd Edition 1996.

8. Sushutra, Ambika Dutta Shastri, Sushutra Samhita with Elaborated Ayurveda Tatva Sandipika Hindi Commentary, Reprint. Varanasi: Choukhambha Sanskrit Sansthan, Su.sha.5/18 p:57.

9. Vagbhatt, Kaviraj Atridev Gupt, Ashtang Hridayam Vidyotini Hindi Commentary, Reprint. Varanasi: Choukhambha Prakashan,2012.

10. Sushutra, Ambika Dutta Shastri, Sushutra Samhita with Elaborated Ayurveda Tatva Sandipika Hindi Commentary, Reprint. Varanasi: Choukhambha Sanskrit Sansthan.Su. Sha.5/22 p 60

11. Kaviraj Ambikadutta Shastri, Sushrut Samhita, Vol 1, Chaukhmba Sanskrit Sansthana, Varanasi 2012. Su.su.14/15 p:66

12. Acharya Vidyadharshukla, Prof. Ravidutta tripathi, Charak Samhita of Agnivesh, Vol.2, Chikitsa Sthana 15/21, Chaukhambha Sanskrit Sansthana 2010

13. Sushutra, Ambika Dutta Shastri, Sushutra Samhita with Elaborated Ayurveda Tatva Sandipika Hindi Commentary, Reprint. Varanasi: Choukhambha Sanskrit Sansthan, Kalp Sthana 4/40

14. Agnivesha; Charak Samhita, English Commentary by R. K. Sharma, Bhagwan DashVol.4 Choukhamba Sanskrit Series Office, Varanasi, Edition2010, ca.chi.15/31p:19

15. Farlex Partmer Medical Dictionary, Farlex 2012.

16. Sushutra, Ambika Dutta Shastri, Sushutra Samhita with Elaborated Ayurveda Tatva Sandipika Hindi Commentary, Reprint. Varanasi: Choukhambha Sanskrit Sansthan.Su. Sha Su.su.15/3.

17. Ashtanga Hridayam of Vagbhata, Vidyotini Hindi Commentary by Kaviraja Atrideva Gupta, Vidyalankara, Bhisagratns, Edited by Vaidya Yadunandana Upadhyaya, Chaukhambha Prakashan, Edition: Reprint 2011, A. Ha. Su11

18. Sushutra, Ambika Dutta Shastri, Sushutra Samhita with Elaborated Ayurveda Tatva Sandipika Hindi Commentary, Reprint. Varanasi: Choukhambha Sanskrit SansthanSu.sha.5/21-23.

19. Sha.pu.5/16-17.

20. Agnivesha; Charak Samhita, English Commentary by R. K. Sharma, Bhagwan DashVol.4Choukhamba Sanskrit Series Office, Varanasi, Edition2010, Cha.chi.15/30. 
21. Agnivesha; Charak Samhita, English Commentary by R. K. Sharma, Bhagwan DashVol.2 Choukhamba Sanskrit Series Office, Varanasi, Edition2010, Cha.vi.8/107 p:269.

22. Sushutra, Ambika Dutta Shastri, Sushutra Samhita with Elaborated Ayurveda Tatva Sandipika Hindi Commentary, Reprint. Varanasi: Choukhambha Sanskrit Sansthan, Su.su. 35/18 p:170.

23. Sushutra, Ambika Dutta Shastri, Sushutra Samhita with Elaborated Ayurveda Tatva Sandipika Hindi Commentary, Reprint. Varanasi: Choukhambha Sanskrit Sansthan, Su.su.15/19 p:78.

24. Agnivesha; Charak Samhita, English Commentary by R. K. Sharma, Bhagwan DashVol.1 Choukhamba Sanskrit Series Office, Varanasi, Edition2010, Cha.su.17/67.

25. Sushutra, Ambika Dutta Shastri, Sushutra Samhita with Elaborated Ayurveda Tatva Sandipika Hindi Commentary, Reprint. Varanasi: Choukhambha Sanskrit Sansthan Su.su.15/13 p:76.

26. Ashtanga Hridayam of Vagbhata, Vidyotini Hindi Commentary by Kaviraja Atrideva Gupta, Vidyalankara, Bhisagratns, Edited by Vaidya Yadunandana Upadhyaya, Chaukhambha Prakashan, Edition: Reprint 2011, A.Ha.Su11A.hr.su.11/28.

\section{Source of Support: Nil}

\section{Conflict of Interest: None Declared}

How to cite this URL: Neetu Soni et al: Physiological Aspects Of Asthidhatu. International Ayurvedic Medical Journal \{online\} 2021 \{cited October 2021\} Available from: http://www.iamj.in/posts/images/upload/2495_2499.pdf 